\title{
EFEKTIVITAS PENGGUNAAN METODE BIL HIKMAH TERHADAP TINGKAT KEMAMPUAN MEMBACA AL-QURĀN ANAK USIA DINI
}

\author{
Indriani Nurzaman, ${ }^{*}$ \\ Program Studi Ilmu Pendidikan Agama Islam, \\ Fakultas Pendidikan Ilmu Pengetahuan Sosial, Universitas Pendidikan Indonesia \\ *Email: indriani.nurzaman@gmail.com
}

\begin{abstract}
ABSTRAK
Penelitian ini dilakukan sebagai salah satu upaya untuk memberantas buta huruf terhadap alQurān sejak dini. Hal ini dikarenakan kegelisahan peneliti yang melihat kenyataan yang ada di lapangan cenderung banyak orang yang belum bisa membaca al-Qurān untuk berbagai kalangan baik itu kanak-kanak, remaja, bahkan orang dewasa. Peneliti khawatir jika hal ini dibiarkan orang yang tidak bisa membaca al-Qurān akan semakin banyak. Peneliti berpendapat pemberantasan buta huruf terhadap al-Qurān ini akan efektif sekali diberikan semenjak dini. Oleh karena itu, salah satu solusinya dengan menerapkan metode Bil-Hikmah dalam pembelajaran membaca al-Qurān anak. Secara umum penelitian ini bertujuan untuk mengetahui dan memperoleh gambaran secara aktual dan faktual mengenai tingkat perkembangan kemampuan membaca al-Qur'ān anak setelah diberi perlakuan dengan menggunakan metode Bil-Hikmah. Penelitian ini dilakukan secara klasikal kepada anak-anak di Majelis Ta'lim Al-Hidayah Cidamar sebanyak 10 orang. Hasil penelitian ini menunjukkan adanya pengaruh yang signifikan antara penggunaan metode Bil-Hikmah terhadap peningkatan kemampuan yang dikuasai oleh anak dalam membaca al-Qurān anak dalam waktu yang relatif singkat. Hasil penelitian ini menjawab persoalan bahwa metode BilHikmah dapat dijadikan sebagai salah satu alternatif dalam membantu meningkatkan kemampuan membaca al-Qurān usia dini. Hasil penelitian ini direkomendasikan untuk guru dapat menggunakan metode Bil- Hikmah dalam pembelajarannya serta media, sehingga metode Bil-Hikmah ini menjadi satu kesatuan yang saling mendukung sehingga berjalan optimal dalam mengefektifkan tingkat kemampuan membaca al-Qurān anak.
\end{abstract}

Kata Kunci: Metode bil Hikmah, Membaca al-Qur'an, Kemampuan Membaca al-Qur'an. 


\section{PENDAHULUAN}

Membaca al-Qurān tidak hanya merupakan suatu keahlian atau keterampilan saja, akan tetapi sudah mutlaq menjadi kewajiban setiap muslim. Oleh karena itu, akan terasa bertolak belakang sekali apabila ada seseorang yang mengaku muslim tetapi tidak bisa membaca al-Qurān. Dalam membaca alQurānpun atau sering juga sebut dengan bertilawah terdapat tiga jenis cara bertilawah yakni: tilawah lafdiyah, tilawah ma'nawiyah, dan tilawah hukmiyah. Tilawah lafdi adalah membaca al- Qurān sesuai dengan lafađnya secara lisan tanpa memahami maknanya. Tilawah ma'nawi adalah jenis membaca al-Qurān yang hanya memahami ma'nanya saja tanpa diiringi dengan pengucapan lisan. Tilawah hukmiyah, yaitu membenarkan segala informasi al-Qur'ān dan menerapkan segala ketetapan hukumnya dengan cara menunaikan perintahperintahNya dan menjauhi laranganlaranganNya. Pada ketiga jenis tilawah di atas pada dasarnya apabila dikerjakan atau diamalkan bagus.

Namun, pada tingkat masyarakat awam dianjurkan terlebih dahulu untuk bertilawah secara lafdiyah baru kemudian bertilawah secara ma'nawiyah dan hukmiyah.

Membaca al-Qurān secara lafdiyah itu terbagi-bagi kedalam empat kategori ada yang secara tahqiq, hadr, tadwir, serta tartil. Membaca al-Qurān yang dianjurkan adalah membaca al-Qurān secara tartil sebagaimana yang telah Allah SWT firmankan dalam (Q.S. Al-Muzzamil: 4) adalah:

Artinya: "Dan bacalah Al-Qurइn secara perlahan-lahan.
Maksud perlahan-lahan di sini adalah haruslah sesuai dengan kaidah tajwidnya yang memenuhi bacaaan hukum-hukumnya serta hak-hak akan huruf-hurufnya itu sendiri.

Selain harus tartil, membaca alQurānpun memiliki keutamaan sebagaimana dijelaskan dalam sebuah hadits Hakim dari Ibnu Mas'ud, AlMalibari (t.t., hal. 53) menyatakan bahwa: "Siapa saja yang membaca satu huruf dari pada al-Qurān maka baginya satu kebaikan, sedangkan satu kebaikan itu dibalas dengan sepuluh kebaikan. Saya tidak berkata alif lam mim itu satu huruf melainkan alif satu huruf, lam satu huruf, dan mim satu huruf “.

Pentingnya anjuran untuk membaca seperti yang telah dikemukakan di atas, bertolak belakang dengan kenyataan yang diinginkan. Berangkat dari hasil observasi yang dilakukan oleh BAQI UPI (Laporan, 2008/2009) menyatakan bahwa:

"Hasil rekaptulasi tes awal baca alQurān mahasiswa UPI peserta tes Baqi Mahasiswa semester ganjil angkatan 2008 per fakultas adalah sebagai berikut: FIP terdapat 7 orang yang tidak lulus TPD1, FPBS terdapat 40 orang yang tidak lulus TPD1, dan FPIPS terdapat 13 orang yang tidak lulus TPD1. Untuk tingkatan TPD2 FIP terdapat 81 orang yang tidak lulus, FPBS terdapat 238 orang yang tidak lulus, FPIPS terdapat 187 orang yang tidak lulus. Untuk tingkatan TD FIP terdapat 220 orang yang tidak lulus, FPBS terdapat 337 orang yang tidak lulus, dan FPIPS terdapat 424 orangyang tidak lulus. Untuk tingkatan TT yang lulus di FIP terdapat 144 orang, FPBS terdapat 227 orang, dan FPIPS terdapat 248 orang. Untuk tingkatan TM FIP terdapat 64 orang, FPBS terdapat 78 orang, dan FPIPS terdapat 63 orang. 
Dari hasil tes tersebut dapat disimpulkan bahwa dari semua fakultas terdapat 50 orang atau $1 \%$ yang termasuk ke dalam tingkat TPD1, 506 orang atau 16\% termasuk ke dalam tingkat TPD2, 981 orang atau $43 \%$ termasuk ke dalam tingkat TD, 619 orang atau $28 \%$ termasuk ke dalam tingkatan TT, dan 205 atau 12\% termasuk ke dalam tingkatanTM. Maka disimpulkan dari data tersebut terdapat $60 \%$ mahasiswa yang tidak bisa membaca al-Qurān".

Guntur (dalam Munawaroh, 2006, hal. 3) mengemukakan pula bahwa:

'Di Indonesia sendiri dengan penduduk Islam terbesar yaitu sekitar 170 juta jiwa ternyata hanya $36 \%$ saja yang bisa membaca al-Qurān, kemudian dari $36 \%$ itu hanya $16 \%$ saja yang bisa membaca dengan tartil dan benar tajwidnya, ironisnya dari $16 \%$ tersebut hanya 3\% saja yang rutin membacanya'.

Kemudian UKM BAQI UPI mengadakan penelitian terhadap mahasiswa semester genap tahun 2009. Tercatat di Fakultas Pendidikan Teknologi dan Kejuruan (FPTK) UPI terhitung dari 382 mahasiswa yang melakukan pre-test hanya 116 mahasiswa yang dinyatakan mampu membaca al-Qurān dengan benar dan atau hanya $30,36 \%$ saja yang dinyatakan lulus pre- test. Sedangkan di Fakultas Pendidikan Matematika dan Ilmu Pengatahuan Alam (FPMIPA) tercatat $54,69 \%$ yang dinyatakan mampu membaca Al-Qurān dengn benar dari 554 mahas is wa yang melakukan pre-test. Dan hasil pretest yang dilakukan UKM BAQI di Fakultas Olahraga dan Kesehatan mencatat hanya $25,37 \%$ saja yang mampu membaca Al- Qurān dengan benar dari 205 mahasiswa yang melakukan pre-test.

Pada hari jumat tepatnya tgl 6 November 2009 lalu peneliti mengadakan pengetesan terhadap siswa dan siswi SD yakni di SD 2 Suntenjaya Lembang pada siswa kelas V dan VI. Ternyata hasil tesnya begitu mencengangkan dari jumlah siswa 40 orang sekitar 97,5\% siswa-siswi tersebut belum bisa atau lancar membaca al-Qurān. Peneliti berkesimpulan sangat wajar apabila saat ini banyak orang yang pintar akan tetapi miskin akhlaknya. Salah satu penyebabnya karena dia tidak tahu akan hal tersebut, jangankan untuk mengerti atau memahami apa-apa yang tertera dalam al-Qurān kalau kemampuan untuk membacanya saja tidak dimiliki.

Data-data di atas mudah-mudahan dapat membuka mata hati untuk bisa menanggulangi buta huruf terhadap alQurān agar tidak semakin memburuk. Ada beberapa faktor yang menyebabkan orangorang tidak pandai membaca al-Qurān salah satunya adalah sebagaimana yang dikemukakan oleh Tim YBHI (2002, hal. 39) bahwa :

"Siapakah siswa dan mahasiswa yang tidak bisa atau belum benar membaca al-Qurān adalah: (1) mereka yang masa kecilnya, pada usia TKdan SD, tidak sempat memasuki Taman Kanak-kanak alQurān (TKA) dan Taman Pendidikan AlQurān (TPA), atau tidak sempat mengaji; (2) mereka yang pernah mengaji tapi keluar dari TKA/TPA-nya sebelum mereka pintar membaca al-Qur'ān; dan (3) mereka yang ikut mengaji di masjid tapi tidak serius belajarnya."

Salah satu faktor yang berpengaruh besar terhadap tingkat pencapaian tujuan dalam pembelajaran adalah metode pembelajaran. Selain itu, faktor yang berpengaruh besar terhadap tingkat kemampuan pembelajaran dalam mempelajari al-Qurān adalah kurang tepatnya memilih metode yang baik untuk anak didiknya. Hal ini dikarenakan metode 
mempunyai pengaruh besar saat kegiatan belajar mengajar berlangsung, yang akan mengantarkan mereka untuk mengerti dan memahami materi yang guru sampaikan. Metode juga bisa dikatakan sebagai motivasi ekstrinsik. Motivasi ekstrinsik menurut Sardiman (dalam Djamarah, 2006, hal. 73) mengemukakan bahwa:

Karena itu, metode berfungsi sebagai alat perangsang dari luar yang dapat membangkitkan belajar seseorang. Makin tepat metode yang digunakan oleh guru dalam mengajar, diharapkan makin efektif pula pencapaian tujuan pembelajaran'.

Masalah ini tidak bisa dianggap hal kecil karena bagaimanapun, pemberantasan buta huruf al-Qurān itu harus ditanggulangi sejak dini, sebab seiring dengan bertambahnya umur maka kemampuan dalam belajarpun semakin lama semakin menurun.

Menurut para ahli, bahwa penanaman sikap beragama sangat baik pada masa anak- anak. Pada masa anakanak (usia 3 sampai 6 tahun) seorang anak memiliki pengalaman agama yang asli dan mendalam, serta mudah berakar dalam diri dan kepribadiannya. Hal tersebut merupakan faktor yang sangat penting melebihi yang lain, karena pada saat itu anak mempunyai sifat wordering atau heran sebagai salah satu faktor untuk memperdalam pemahaman spiritual reality.

Dalam rangka meningkatkan kualitas sumber daya manusia maka pengembangan iman dan taqwa sangat penting ditanamkan sejak dini, sebagai pondasi awal membangun generasi muda bangsa. Salah satu diantaranya dengan memperkenalkan kitab suci al-Qurān. Kurangnya minat membaca ini mungkin disebabkan metode pembelajaran al-Qurān kurang menarik dan cenderung monoton. Oleh karena itu, perlu adanya motivasi yang dapat membawa anak ingin belajar al- Qurān secara menarik.

Dalam mengenalkan kitab suci alQurān terdapat beberapa metode yang ditawarkan diantaranya: metode Iqro, metode Ihsan, metode Al-Bana, metode Al-Barqy, metode Jabari, metode Thagona, dan metode Bil-Hikmah

Melihat problematika tersebut, maka diambil satu permasalahan pemberantasan buta huruf terhadap alQurān sejak dini. Peneliti akan mengamati efektivitas penggunaan metode Bil Hikmah terhadap tingkat kemampuan membaca al-Qurān anak usia dini. Untuk membuktikan apakah metode tersebut efektif dan efisien dalam mempengaruhi kemampuan perkembangan membaca alQurān anak.

Berdasarkan latar belakang yang telah dikemukakan di atas maka penulis merumuskan masalah terhadap. "Bagaimana Efektivitas Penggunaan Metode Bil Hikmah Terhadap Peningkatan Kemampuan Membaca Anak Usia Dini?"

Maka dilihat dari problematika di atas, untuk memudahkan penelitian yang akan dilakukan, peneliti membuat pertanyaan-pertanyaan penelitian sebagai berikut: (1)Bagaimana kondisi awal kemampuan membaca al-Qurān anak sebelum mendapat perlakuan dengan menggunakan metode Bil-Hikmah? (2)Bagaimana proses kegiatan belajar mengajar dengan menggunkaan metode Bil-Hikmah? (3)Bagaimana kondisi akhir kemampuan membaca al-Qurān anak setelah mendapatkan perlakuan dengan menggunakan metode Bil-Hikmah? (4) Apakah metode Bil-Hikmah efektif dalam meningkatkan kemampuan membaca alQurān anak? 


\section{KAJIAN PUSTAKA}

Membaca Al-Qurān merupakan suatu kewajiban yang harus dilakukan oleh umat Islam. Karena Al-Qurān lah yang merupakan pedoman dan tuntunan hidup umat manusia. Sebagimana perintah yang pertama kali Allah wahyukan kepada nabi Muhammād SAW adalah surat Al-'Alaq ayat $1-5$ yang artinya:

"Bacalah dengan (menyebut) nama Tuhanmu yang Menciptakan, Dia telah menciptakan manusia dari segumpal darah. Bacalah, dan Tuhanmulah yang Maha pemurah, yang mengajar (manusia) dengan perantaran kalam.

Dia mengajar kepada manusia apa yang tidak diketahuinya”.

Pengajaran yang dimaksud di ayat ini menurut para ahli tafsir adalah mengajarkan membaca dan menulis alQurān. Iqra atau perintah membaca merupakan kata pertama dan juga mendapat peran yang penting karena mendapatkan pengulangan selama dua kali.

Sebagaimana yang dijelaskan oleh Syarifuddin (2007, hal. 20) menjelaskan bahwa:

"Kata iqra yang diambil dari kata dasar qaraa pada mulanya berarti 'menghimpun'. Arti kata ini menunjukkan bahwa iqra yang diterjmahkan dengan 'bacalah' tidak mengharuskan adanya teks tertulis yang dibaca, tidak pula harus diucapkan sehingga terdengar oleh orang lain. Dalam kamus bahasa, ditemukan aneka ragam arti dari kata iqra tersebut, antara lain: menyampaikan, menelaah, membaca, mendalami, meneliti, mengetahui ciri-cirinya, dan sebagainya yang kesemuanya dapat dikembalikan kepada hakikat "menghimpun" yang merupakan arti akar kata tersebut"

Perintah iqra mendorong agar umat manusia berfikir dan bertafakur mempergunakan potensi akalnya. Hal ini juga diperkuat oleh salah satu hadits yang mengungkapan seruan anak membaca alQurān yakni:

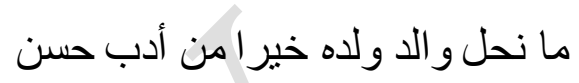

Artinya: "Orang tua tidak memberi anak suatu pemberian yang lebih baik daripada (memberi) pendidikan yang bagus". (HR Tirmidzi dan Al-Hakim)

Maksud pendidikan yang bagus yang dimaksud oleh hadits di atas adalah pendidikan paling mulia yakni pendidikan al-Qurān. Beberapa pepatah telah menggambarkan keutamaan untuk membaca al-Qurān diantaranya yaitu:

a. Sebagaimana hadits Nabi SAW yakni:

$$
\text { خيركم من تعلّم القر آن و علّمه }
$$

Artinya: "Sebaik-baiknya kamu adalah orang yang belajar al-Qur'an dan mengajarkannya". (HR. Bukhari)

Dalam beberapa hadits ada dua macam cara membaca al-Qurān yakni: secara sirri dan jahr. Membaca al-Qurān secara jahr disunnahkan dalam hadits Shahih Bukhari dan Muslim sebagaimana haditsnya yang berbunyi:

$$
\begin{aligned}
& \text { ما ادن الله لثيء ما ادن لنبيّ حسن الصوت } \\
& \text { يتغني بالقر آن يجهر به اله } \\
& \text { Sedangkan membaca al-Qurān } \\
& \text { secara sirri disunnahkan dalam hadits }
\end{aligned}
$$


yang diriwayatkan oleh Abi Daud, Tirmidzi, dan Nasa'i yang berbunyi:

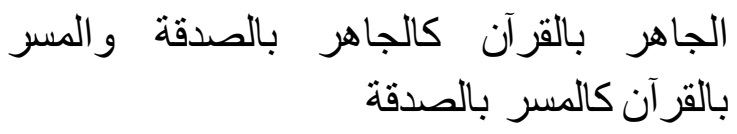

Menurut Imam Nawawi mengumpulkan antara keduanya itu akan utama disesuaikan dengan ilatnya. Bahwasannya sirri itu lebih utama apabila orang yang membacanya takut akan ria, mengganggu orang yang salat, dan mengganggu orang yang tidur. Sedangkan jahr juga lebih utama tatkala tidak ada niat untuk ria dan sebagainya. Hal tersebut dikarenakan beramal secara jahr itu lebih banyak faedahnya diantaranya memberikan kesempatan kepada orang lain untuk mendengarkannya, menggugah hati orang yang membaca untuk berpikir, dan lain sebagainya.

\section{METODE}

Metode yang digunakan dalam penelitian ini dinamakan dengan metode eksperimental. Pola eksperimen ini termasuk ke dalam kelompok preeksperimental atau dinamakan dengan quasi-experimental. Penelitian ini hanya menggunakan satu kali pengukuran terhadap variabel terikat di awal sebelum melakukan treatment kemudian dilakukan pengukuran kembali setelah treatment.

Desain penelitian adalah sebuah peta jalan bagi peneliti yang menuntun serta menentukan arah berlangsungnya proses penelitian secara benar dan tepat sesuai dengan tujuan yang telah ditetapkan (Sarwono, 2006, hal. 79).

Pola desain riset yang digunakan dalam penelitian ini adalah desain riset konklusif, yang termasuk pula ke dalam riset kausal yakni suatu penelitian yang digunakan untuk mengidentifikasi hubungan sebab akibat antar variabelvariabel. Variabel bebas dalam penelitian ini yang akan memberikan pengaruh kepada variabel terikatnya, oleh karena itu penelitian ini termasuk ke dalam penelitian eksplanatori. Secara spesifiknya penelitian ini dikategorikan sebagai penelitian eksperimental lapangan field experiment.

Desain eksperimental yang digunakan pada penelitian ini adalah One Group Pre-test - Post-test design. Yakni desain yang digunakan untuk meneliti pada satu kelompok dengan cara melakukan satu kali pengukuran di depan pre-test treatment dan setelah itu dilakukan pengukuran lagi post-test.

Pola desainnya adalah sebagai berikut:

Tabel 1

Pola Desain Penelitian 1

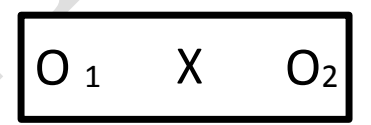

Keterangan:

O1 : Pre-test sebelum adanya treatment

O2 : Post-test setelah dilakukan treatment

$\mathrm{X}$ : Treatment dengan menggunakan metode Bil Hikmah

Namun karena penelitian ini dilakukan secara berulang-ulang dalam kurun waktu tertentu maka diberlakukan desain time series. Pola desainnya berubah menjadi:

Tabel 2

Pola Desain Penelitian 2

$$
\begin{gathered}
\mathrm{O}_{1} \mathrm{O}_{2} \mathrm{O}_{3} \mathrm{O}_{4} \mathrm{O}_{5} \mathrm{O}_{6} \mathrm{O}_{7} \mathrm{O}_{8} \mathrm{O}_{9} \mathrm{O}_{10} \mathrm{O}_{\mathrm{n}} \mathrm{X} \\
\mathrm{O}_{\mathrm{n}} \mathrm{O}_{\mathrm{n}} \mathrm{O}_{\mathrm{n}} \mathrm{O}_{\mathrm{n}} \mathrm{O}_{\mathrm{n}} \mathrm{O}_{\mathrm{n}} \mathrm{O}_{\mathrm{n}} \mathrm{O}_{\mathrm{n}} \mathrm{O}_{\mathrm{n}} \mathrm{O}_{\mathrm{n}} \mathrm{O}_{\mathrm{n}}
\end{gathered}
$$




\section{HASIL DAN PEMBAHASAN}

Sampel diambil dari siswa-siswi majelis ta'lim yang terdiri dari 20 siswa, kelompok A terdiri dari 10 orang dan kelompok B erdiri dari 10 orang. Namun pada pelaksanaannya, kelompok A saja yang diamati karena hanya kelompok A saja yang siswa-siswinya digolongkan ke dalam kriteria usianya masih kanak-kanak yakni masih taraf PAUD, TK, dan SD.

Pada penelitian ini ada 51 indikator atau standardisasi sebagai acuan observasi dan wawancara, pada pre-test dan posttest. Teknik wawancara digunakan untuk mengukur kemampuan menyebutkan/ membaca bunyi huruf hijaiyah. Sementara teknik observasi digunakan untuk mengukur kemampuan mengenali bentuk bunyi huruf hijaiyah.

Hasil pre-test dan post-test selanjutnya dikategorisasikan sesuai menurut tingkatannya. Kategorisasi yang digunakan terdiri dari TPD, TD, dan TT dengan menggunakan kategorisasi yang sama dengan kategorisasi kemampuan membaca al-Qurān menurut metode BilHikmah.

Penelitian ini dilaksanakan selama 40 kali pertemuan yaitu sejak tanggal 23 Maret 2011 sampai tanggal 31 Mei 2011, terbagi kedalam tiga tahapan sebagai berikut yakni:

a) Pre-test

Tahap pertama yaitu pelaksanaan pre- test tentang kemampuan membaca alQur'an. Hal ini dilakukan untuk mengetahui kondisi awal kemampuan membaca al- Qurān anak majelis ta' lim alHidayah sebelum mendapat perlakuan. Pre-test dilakukan di awal pertemuan yakni pada tanggal 23 Maret 2011. Pedoman pre-test yang digunakan terdiri dari 51 indikator sesuai dengan pokokpokok pengajaran dalam metode BilHikmah yang kemudian dimasukan ke dalam tiga kategorisasi tingkat kemampuan membaca al-Qur'annya.

b) Pelaksanaan Treatment atau Perlakuan

Tahap kedua yaitu pelaksanaan treatment atau perlakuan pembelajaran membaca al-Qurān kelompok A dengan menggunakan metode Bil-Hikmah. Treatment dilaksanakan selama 40 kali pertemuan, dengan durasi 90 Menit dalam setiap pertemuannya. Adapun tahapan pembelajarannya dengan menggunakan metode Bil- Hikmah bervariasi hal ini disebabkan karena tidak sama tingkat kemampuan membacanya pada awal pretest.

c) Pelaksanaan Post-test

Tahap ketiga yaitu pelaksanaan post-test tentang kemampuan membaca alQur'an, setelah diberikan perlakuan. Posttest dilakukan untuk mengetahui kondisi akhir kemampuan membaca al-Qurān anak Majelis ta'lim al-Hidayah setelah mendapatkan perlakuan pembelajaran membaca al-Qurān dengan menggunakan metode Bil-Hikmah. Pelaksanaan post-test dilaksanakan pada kelompok A yang dilaksanakan pada hari selasa tanggal 31 Mei 2011. Pedoman post-test yang digunkan sama dengan yang digunakan pada saat pelaksanaan pre-test yaitu terd iri dari 51 indikator.

Pelaksanaan kegiatan belajar mengajar dilakukan 4-5 hari dalam satu minggu. Bahan dan kegiatan pembelajaran yang peneliti terapkan di sesuaikan dengan garis besar pengajaran memebaca dan menulis al-Qurān metode Bil-Hikmah. Adapun pokok-pokok bahasan yang ada dalam pengajaran membaca menurut metode Bil-Hikmah diantaranya yaitu: 
Tabel 4

Gambaran Pokok Bahasan/ Indikator Dalam Pengajaran Baca AlQurān Dengan Menggunakan Metode Bil-Hikmah

\begin{tabular}{|c|c|c|c|}
\hline No. & Pokok Bahasan/Indikator & Halaman & Jilid \\
\hline 1. & Huruf Hijaiyah & $4-6$ & 1 \\
\hline 2. & Pemantapan Bacaan Huruf Hijaiyah & $7-18$ & 1 \\
\hline 3. & Evaluasi bacaan berharakat fathah & 19 & 1 \\
\hline 4. & Bacaan berharakat kasrah & $22-23$ & 1 \\
\hline 5. & $\begin{array}{l}\text { Bacaan variasi harakat fathah dan } \\
\text { kasrah }\end{array}$ & 24 & 1 \\
\hline 6. & Bacaan berharakat dhomah & $26-28$ & 1 \\
\hline 7. & $\begin{array}{l}\text { Kombinasi harakat fathah,kashrah, } \\
\text { dan dhomah }\end{array}$ & 30 & 1 \\
\hline 8. & $\begin{array}{l}\text { Kombinasi harakat fathah, kasrah, } \\
\text { dhomah tiga suku kata }\end{array}$ & 31 & 1 \\
\hline 9. & $\begin{array}{l}\text { Kombinasi harakat fathah, dhomah, } \\
\text { kasrah empat suku kata. }\end{array}$ & 32 & 1 \\
\hline 10. & Bacaan tanwin fathah & 34 & 1 \\
\hline 11. & $\begin{array}{l}\text { Kombinasi bacaan harakat fatahah } \\
\text { dengan tanwin fathah. }\end{array}$ & 35 & 1 \\
\hline 12. & Bacaan tanwin kasrah. & 36 & 1 \\
\hline 13. & $\begin{array}{l}\text { Kombinasi harakat kasrah dengan } \\
\text { tanwin kasrah. }\end{array}$ & 37 & 1 \\
\hline 14. & $\begin{array}{l}\text { Kombinasi harakat tanwin fathah } \\
\text { dengan tanwin kasrah. }\end{array}$ & 38 & 1 \\
\hline 15. & Bacaan harakat tanwin dhomah & 39 & 1 \\
\hline 16. & $\begin{array}{l}\text { Kombinasi harakat dhomah dengan } \\
\text { tanwin dhomah }\end{array}$ & 40 & 1 \\
\hline 17. & $\begin{array}{l}\text { Kombinasi bacaan tanwin fathah, } \\
\text { tanwin kasrah, dan tanwin dhomah. }\end{array}$ & 41 & 1 \\
\hline 18. & $\begin{array}{l}\text { Kombinasi bacaan fatahah, tanwin } \\
\text { fathah, kasrah, tanwin kasrah, } \\
\text { dhomah, tanwin dhomah. }\end{array}$ & $42-43$ & 1 \\
\hline 19. & $\begin{array}{l}\text { Kombinasi bacaan fathah, kasrah, } \\
\text { dhomah, tanwin fathah, tanwin } \\
\text { kasrah, dan tamnwin dhomah secara } \\
\text { acak tiga suku kata. }\end{array}$ & $44-45$ & 1 \\
\hline 20. & $\begin{array}{l}\text { Memperkenalkan huruf hijaiyah } \\
\text { sambung }\end{array}$ & $3-6$ & 2 \\
\hline 21. & Pengenalan huruf sambung. & 7 & 2 \\
\hline 22. & $\begin{array}{l}\text { Aplikasi huruf hijaiyah sambung tiga } \\
\text { suku kata. }\end{array}$ & $8-14$ & 2 \\
\hline 23. & $\begin{array}{llll}\text { Evaluasi } & \text { bacaan } & \text { huruf } & \text { hijaiyah } \\
\text { sambung. } & & & \end{array}$ & 15 & 2 \\
\hline 24. & $\begin{array}{l}\text { Aplikasi bacaan sukun di akhir } \\
\text { kalimat. }\end{array}$ & 20 & 2 \\
\hline 25. & $\begin{array}{l}\text { Aplikasi bacaan sukun } \\
\text { kalimat dan diakhir }\end{array}$ & 21 & 2 \\
\hline 26. & $\begin{array}{l}\text { Aplikasi bacaan sukun di tengah } \\
\text { kalimat atau bacaan. }\end{array}$ & 22 & 2 \\
\hline 27. & Bacaan alif lam qomariyah. & 23 & 2 \\
\hline
\end{tabular}




\begin{tabular}{|c|c|c|c|}
\hline 28. & $\begin{array}{l}\text { Aplikasi bacaan alif lam qomariyah } \\
\text { pada dua kalimat. }\end{array}$ & 24 & 2 \\
\hline 29. & Bacaan tasydid. & 25 & 2 \\
\hline 30. & Bacaan alif lam syamsiah. & 26 & 2 \\
\hline 31. & $\begin{array}{l}\text { Aplikasi bacaan alif lam syamsiah } \\
\text { pada dua kalimat. }\end{array}$ & 27 & 2 \\
\hline 32. & $\begin{array}{l}\text { Aplikasi bacaan alif lam qomariyah } \\
\text { dan alif lam syamsiah dan tasydid } \\
\text { pada dua kalimat. }\end{array}$ & $29-30$ & 2 \\
\hline 33. & Evaluasi jilid II & $31-32$ & 3 \\
\hline 34. & $\begin{array}{l}\text { Membandingkan bacaan panjang dan } \\
\text { pendek. }\end{array}$ & 3 & 3 \\
\hline 35. & $\begin{array}{l}\text { Bacaan panjang mad asli atau mad } \\
\text { tabi'i }\end{array}$ & $4-10$ & 3 \\
\hline 36. & Bacaan pendek mad layyin. & 11 & 3 \\
\hline 37. & $\begin{array}{l}\text { Aplikasi bacaan panjang mād thobi'i } \\
\text { dan pendek mād layin. }\end{array}$ & 12 & 3 \\
\hline 38. & $\begin{array}{l}\text { Bacaan huruf-huruf kritis yang } \\
\text { berdekatan makharijul hurufnya. }\end{array}$ & $13-20$ & 3 \\
\hline 39. & Bacaan idghom. & 21 & 3 \\
\hline 40. & Memendekkan bacaan panjang. & 22 & 3 \\
\hline 41. & Bacaan waqaf. & $23-25$ & 3 \\
\hline 42. & Bacaan mad arid li sukun. & 26 & 3 \\
\hline 43. & Bacaan ta marbutah. & 27 & 3 \\
\hline 44. & Bacaan madiwad. & 28 & 3 \\
\hline 45. & Bacaan iqlab. & 29 & 3 \\
\hline 46. & Bacaan idzhar. & 30 & 3 \\
\hline 47. & Bacaan $i k h f a$. & 31 & 3 \\
\hline 48. & $\begin{array}{l}\text { Bacaan mad jaiz munfasil, dan mad } \\
\text { wajib mutasil. }\end{array}$ & 32 & 3 \\
\hline 49. & Bacaan huruf di awal surat. & 33 & 3 \\
\hline 50. & Evaluasi jilid III. & $34-35$ & 3 \\
\hline 51. & $\begin{array}{l}\text { Strategi penghalusan makharijul } \\
\text { huruf. }\end{array}$ & $36-37$ & 3 \\
\hline
\end{tabular}


Implementasi metode Bil Hikmah dalam pembelajaran antara lain:

a) Peneliti melakukan Tanya jawab tentang gambar huruf hijaiyah beserta analogi gambarnya. Guru mempraktekkan cara pelafalan huruf hijaiyah.

b) Peneliti menjelaskan tata cara bermain kartu, bermain bendera, serta puzzle.

c) Peneliti membagi anak-anak menjadi tiga kelompok sesuai dengan tingkat indikator yang sudah dikuasai.

d) Setiap kelompok maju satu persatu kemudian melakukan pembelajaran bersama dengan menggunakan alat peraga kemudian dilakukan pembelajaran klasikal satun persatu sesuai dengan panggilan dengan menggunakan Bil-Hikmah jilid I,II, dan III.

e) Untuk anak-anak yang menunggu panggilan melakukan permainan bersama dengan teman-temannya baik menggunakan bendera, kartu hijaiyah, maupun puzzle.

f) Selanjutnya anak-anak diberikan PR untuk menulis huruf hijaiyah dengan diberikan penjelasan dan contoh terlebih dahulu.

Berikut adalah hasil penelitian, yaitu perkembangan kemampuan membaca dengan menggunakan metode Bil Hikmah.

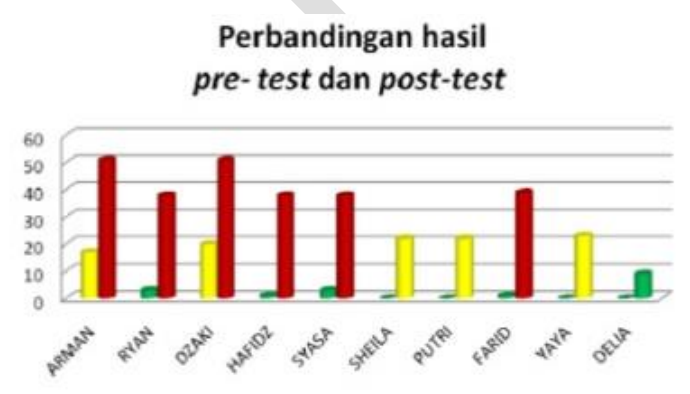

\section{KESIMPULAN}

Metode Bil Hikmah ini merupakan salah satu metode yang dapat dijadikan alat atau sarana yang menunjang dalam proses pembelajaran membaca al-qurān yang menarik, efektif, juga efisien.

Landasan serta prinsip pengajaran dalam metode Bil Hikmah ini dikemas sedemikian menarik dan juga tidak membosankan untuk anak-anak. Sehingga dalam proses pembelajarannya tidak akan menimbulkan rasa yang membosankan. Hal ini didukung pula oleh alat peraga dan sistem media evaluasi yang menyenangkan yakni bermain sambil belajar.

Hasil penelitian ini berimplikasi bahwa metode Bil Hikmah dapat digunakan dalam pembelajaran membaca al-Qurān untuk meningkatkan kemampuan membaca al-Qurān khususnya anak-anak dalam waktu yang relatif singkat.

Untuk memperkaya khazanah metode pendidikan membaca al- qurān, perlu dikembangkan terus dan membuat metode yang lain yang lebih menarik serta efektif, dan efisien tanpa harus mengurangi nilai-nilai pembelajaran yang ada dan harus tetap ada di dalamnya. Hal ini agar tidak hanya siswa pandai tetapi pandai yang bertanggungjawab yakni pandai yang tetap menjunjung tinggi akhlaqal-karimah.

\section{REFERENSI}

Abdurrahman, M. (2003). Pendidikan Bagi Anak Berkesulitan Belajar. Jakarta: Rineka Cipta.

Al-Malibari, S. Z. (t.t.). Irsyadul 'Ibad. Semarang: Toha Putra.

Al-Qattan, M. K. (2007). Studi Ilmu-Ilmu Qur'an. Bogor: Litera Antar Nusa.

Arikunto, S. (2006). Prosedur Penelitian Pendidikan. Jakarta: Rineka Cipta. 
Ash-Shiddieqy, H. (1992). Sejarah dan Pengantar Ilmu Al-Qur'an/ Tafsir. Jakarta: Bulan Bintang.

As-Suyuthi, J. A. (1967). Al-Itqan fi Ulum Al-Qur'an. Libanon: Makatabah Darul Fikr.

Desmita. (2010). Psikologi Perkembangan Peserta Didik. Bandung: PT Remaja Rosda Karya.

Djamarah, S. B. (2006). Strategi Belajar Mengajar. Jakarta: Rineka Cipta.

Franz, K. (1994). Membina Minat Baca. Bandung: Rosda Karya.

Istianah, I. (2010). Skripsi PG PAUD Universitas Pendidikan Indonesia. Implementasi Metode Bil Hikmah dalam Mengenalkan Membaca AlQur'an pada Anak TK di RA AlWashiliyah. Bandung.

Jabbar, U. A. (1981). Muntakhobat II. Surabaya: Maktabah 'Ashriyah.

Lencep, A. (2010). Konsep Efektivitas Pembelajaran. Dipetik Juli 19, 2011, dari https://andylecep. wordpress.com/ta $\mathrm{g} /$ metode-pembelajaran/

Mahmud, M. (t.t.). Hidayatul Mustafid fi Ahkamit Tajwid. Serang: Maktabah Iqbal.

Munawaroh, N. M. (2006). Skripsi PG PAUD Universitas Pendidikan Indonesia. Efektivitas Metode Taghona dalam Meningkatkan Kemampuan Membaca Al-Qur'an Anak TK. Bandung.

Sarwono. (2006). Metode Penelitian. Jakarta: Rineka Cipta.
Soenarto, A. (1988). Pelajaran Tajwid Praktis dan Lengkap. Jakarta: Bintang Terang.

Sudjana, N., \& Ibrahim. (2009). Penelitian dan Penilaian Pendidikan. Bandung: Sinar Baru Algesindo.

Supriadi, U. (2003). Studi Efektivitas Kutab Bil Hikmah dalam Upaya Pemberantasan Buta Huruf AlQur'an pada Mahasiswa UPI. Jurnal Kajian Pendidikan Islam, I(1), 8092.

Syarifudin, A. (2007). Mendidik Anak Membaca, Menulis, dan Mencintai Al-Qur'an. Jakarta: Gema Insani Press.

Tampubolon. (1991). Mengembangkan Minat dan Kebiasaan Membaca pada Anak. Bandung: Angkasa.

Tarigan, H. G. (2008). Membaca Sebagai Suatu Keterampilan Berbahasa. Bandung: Angkasa.

Tim Instruktur YBHI. (2002). Metode Bil Hikmah dan Penyelenggaran $P P B Q$. Bandung: Yayasan Baitul Hikmah Indonesia.

Wildan, Y. (2010). Bil Hikmah (Metode Terpadu) Cepat Membaca AlQur'an. Bandung: Fakultas Dakwah UNISBA \& Yayasan Baitul Hikmah Indonesia.

Zamuji. (2008). Terjemah Ta'lim Muta'allim. Surabaya: Menara Suci. 